CrossMark

\& click for updates

Cite this: Food Funct., 2015, 6, 56

\section{Infusions of artichoke and milk thistle represent a good source of phenolic acids and flavonoids}

\author{
Carla Pereira, ${ }^{\mathrm{a}, \mathrm{b}}$ Lillian Barros, ${ }^{\star a}$ Ana Maria Carvalho, ${ }^{\mathrm{a}}$ Celestino Santos-Buelga ${ }^{\mathrm{b}}$ and \\ Isabel C. F. R. Ferreira*a
}

\begin{abstract}
Cynara scolymus L. (artichoke) and Silybum marianum (L.) Gaertn (milk thistle) are two herbs well-known for their efficiency in the prevention/treatment of liver injuries, among other chronic diseases. Therefore, the aim of this work was to characterize specific bioactive components, phenolic compounds, in hydromethanolic extracts but also in infusions (the most commonly used preparations) obtained from the whole plant of milk thistle and artichoke. The phenolic profiles were accessed using HPLC-DAD-MS/ESI. Infusions of both species presented higher phenolic contents than the hydromethanolic extracts. Milk thistle presented a similar phenolic composition between the two preparations, revealing only differences in the quantities obtained. Nevertheless, artichoke revealed a slightly different profile considering infusion and hydromethanolic extracts. Apigenin-7-O-glucuronide was the major flavonoid found in milk thistle, while luteolin-7-O-glucuronide was the most abundant in artichoke. Therefore, infusions of both artichoke and milk thistle represent a good source of bioactive compounds, especially phenolic acids and flavonoids.
\end{abstract}

Received 17th September 2014
Accepted 17th October 2014

DOI: $10.1039 /$ c4fo00834k

www.rsc.org/foodfunction nisms. ${ }^{9,10}$ Besides their strong antioxidant activity, phenolic compounds also revealed a capacity to inhibit the growth of tumor cell lines such as mammary, epidemoid, and hepatocellular carcinoma, among others, in a large number of studies. ${ }^{11}$

Artichoke (Cynara scolymus L.) and milk thistle (Silybum marianum (L.) Gaertn) are two medicinal plants in which phenolic compositions of hydroalcoholic extracts were documented in different studies ${ }^{12-17}$ due to their implication in these herbs' major medicinal properties, including antioxidant, chemopreventive, hepatoprotective and antiviral. ${ }^{18,19}$

In previous studies, artichoke hydroalcoholic extracts have proved to be a good source of flavonoids such as luteolin and apigenin glycosides, and mono-/di-caffeoylquinic acids and derivatives, the main factors responsible for its therapeutic effects. ${ }^{16,20}$ On the other hand, the medicinal properties of milk thistle are attributed to a polyphenolic mixture known as silymarin (present in the seeds), which contains several flavonolignans that are diastereomeric and/or constitutional isomers of each other, including silybin A, silybin B, isosilybin A, isosilybin B, silychristin, isosilychristin, and silydianin. ${ }^{14,17,19,21-27}$

Artichoke and milk thistle can be directly consumed in the diet or taken as infusions, among other available formulations, ${ }^{18,28}$ allowing the dietary polyphenolic compounds to be absorbed through the gastrointestinal tract to reach the liver, where they are mainly metabolized. ${ }^{6}$ Thus, in the present work, the aim was to obtain the phenolic profile of the most common parts used to prepare the infusions of these plants instead of their isolated parts that have already been well-reported as rich sources of these bioactive compounds; for that purpose, the

\footnotetext{
${ }^{a}$ Mountain Research Centre (CIMO), ESA, Polytechnic Institute of Bragança, Campus de Santa Apolónia, Apartado 1172, 5301-855 Bragança, Portugal. E-mail: iferreira@iph.pt, lillian@ipb.pt; Fax:+351-273-325405; Tel: $+351-273-303219$

${ }^{b}$ GIP-USAL, Faculty of Pharmacy, University of Salamanca, Campus Miguel de Unamuno, 37007 Salamanca, Spain
} 
phenolic profiles of hydromethanolic extracts and infusions prepared from the whole plant were assessed and compared.

\section{Experimental}

\section{Samples}

Cynara scolymus L. (artichoke) and Silybum marianum (L.) Gaertn (milk thistle) were obtained from a herbalist shop in Bragança (Portugal) as dry material (mainly flowering stems, capitula and involucral bracts in both cases and leaves as well in the Silybum sample). The botanical identification was confirmed by Ana Maria Carvalho, responsible for the medicinal plant collection in the Herbarium of the Escola Superior Agrária (BRESA) of the Polytechnic Institute of Bragança (Trás-os-Montes, Portugal), where voucher specimens were deposited (artichoke - code 9611; milk thistle - code 9612).

All the samples were reduced to powder and subjected to different preparations: (i) Hydromethanolic extraction: each sample ( $1 \mathrm{~g}$ ) was extracted by stirring with $25 \mathrm{~mL}$ of methanolwater $\left(80: 20, \mathrm{v} / \mathrm{v}, 25^{\circ} \mathrm{C}\right.$ at $\left.150 \mathrm{rpm}\right)$ for $1 \mathrm{~h}$ and subsequently filtered through Whatman No. 4 paper. The residue was then extracted with an additional $25 \mathrm{~mL}$ of methanol-water $(80: 20$, $\mathrm{v} / \mathrm{v}$ ) for another hour. The combined extracts were evaporated at $40{ }^{\circ} \mathrm{C}$ using a rotary evaporator (Büchi R-210, Flawil, Switzerland), frozen and lyophilized; (ii) Infusion preparation: each sample $(1 \mathrm{~g})$ was added to $200 \mathrm{~mL}$ of boiling distilled water and allowed to stand at room temperature for $5 \mathrm{~min}$, and then filtered under reduced pressure; afterwards, the obtained infusion was frozen and lyophilized (FreeZone 4.5, Labconco, Kansas City, MO, USA).

\section{Standards and reagents}

HPLC-grade acetonitrile was obtained from Merck KgaA (Darmstadt, Germany). Formic acid was purchased from Prolabo (VWR International, Fontenay-sous-Bois, France). Phenolic standards were from Extrasynthèse (Genay, France). Water was treated with a Milli-Q water purification system (TGI Pure Water Systems, Greenville, SC, USA).

\section{Phenolic compound extraction and analysis}

The previously described hydromethanolic extracts and infusions were dissolved in water-methanol $(80: 20, \mathrm{v} / \mathrm{v})$ and water, respectively (final concentration $20 \mathrm{mg} \mathrm{mL}^{-1}$ ) and analysed using a Hewlett-Packard 1100 chromatograph (HewlettPackard 1100, Agilent Technologies, Santa Clara, CA, US) with a quaternary pump and a diode array detector (DAD) coupled to an HP Chem Station (rev. A.05.04) data-processing station. A Waters Spherisorb S3 ODS-2 $\mathrm{C}_{18}, 3 \mu \mathrm{m}(4.6 \mathrm{~mm} \times 150 \mathrm{~mm})$ column thermostatted at $35{ }^{\circ} \mathrm{C}$ was used. The solvents used were: (A) $0.1 \%$ formic acid in water and (B) acetonitrile. The elution gradient established was isocratic $15 \%$ for $5 \mathrm{~min}$, $15 \%$ B to $20 \%$ B over $5 \mathrm{~min}, 20-25 \%$ B over $10 \mathrm{~min}, 25-35 \%$ B over $10 \mathrm{~min}, 35-50 \%$ for $10 \mathrm{~min}$, and re-equilibration of the column, using a flow rate of $0.5 \mathrm{~mL} \mathrm{~min}^{-1}$. Double online detection was carried out in the DAD using $280 \mathrm{~nm}$ and
$370 \mathrm{~nm}$ as preferred wavelengths and in a mass spectrometer (MS) connected to an HPLC system via the DAD cell outlet.

MS detection was performed on an API 3200 Qtrap (Applied Biosystems, Darmstadt, Germany) equipped with an ESI source and a triple quadrupole ion trap mass analyzer that was controlled using the Analyst 5.1 software. Zero grade air served as the nebulizer gas (30 psi) and the turbo gas for solvent drying $\left(400{ }^{\circ} \mathrm{C}, 40 \mathrm{psi}\right)$. Nitrogen served as the curtain (20 psi) and collision gas (medium). The quadrupoles were set at unit resolution. The ion spray voltage was set at $-4500 \mathrm{~V}$ in the negative mode. The MS detector was programmed for recording in two consecutive modes: enhanced MS (EMS) and enhanced product ion (EPI) analyses. EMS was employed to show full scan spectra so as to obtain an overview of all of the ions in the sample. The settings used were: declustering potential (DP) $-450 \mathrm{~V}$, entrance potential (EP) $-6 \mathrm{~V}$, and collision energy (CE) -10 V. EPI mode analysis was performed in order to obtain the fragmentation pattern of the parent ion(s) in the previous scan using the following parameters: DP $-50 \mathrm{~V}, \mathrm{EP}-6 \mathrm{~V}$, CE $-25 \mathrm{~V}$, and collision energy spread (CES) $0 \mathrm{~V}$. Spectra were recorded in negative ion mode between $\mathrm{m} / \mathrm{z} 100$ and 1500 .

The phenolic compounds were identified by comparing their retention time, UV-vis and mass spectra with those obtained from standard compounds when available. Otherwise, peaks were tentatively identified comparing the obtained information with available data reported in the literature. For the quantitative analysis, a calibration curve for each available phenolic standard was constructed based on the UV signal: apigenin-7-O-glucoside $\left(y=159.62 x+7.5025 ; R^{2}=0.999\right)$; caffeic acid $\left(y=611.9 x-4.5733 ; R^{2}=0.999\right)$; chlorogenic acid $\left(y=313.03 x-58.2 ; R^{2}=0.999\right) ; p$-coumaric $(y=884.6 x+$ 184.49; $\left.R^{2}=0.999\right)$; ferulic acid $(y=505.97 x-64.578)$; kaempferol-3-O-glucoside ( $\left.y=288.55 x-4.0503 ; R^{2}=1\right)$; kaempferol-3$O$-rutinoside $\left(y=239.16 x-10.587 ; R^{2}=1\right)$; luteolin-7-O-glucoside $\left(y=80.829 x-21.291 ; R^{2}=0.999\right)$; protocatechuic acid $\left(y=291.1 x-6.4558 ; R^{2}=0.999\right) ;$ quercetin-3-O-glucoside $(y=$ $\left.363.45 x+117.86 ; R^{2}=0.999\right)$, and quercetin-3-O-rutinoside $(y=$ $281.98 x-0.3459 ; R^{2}=1$ ). For the identified phenolic compounds for which a commercial standard was not available, the quantification was performed through the calibration curve of other compounds from the same phenolic group. The results were expressed as mg per $\mathrm{g}$ of lyophilized infusion or extract.

\section{Statistical analysis}

For each species, three samples were used and all the analyses were carried out in triplicate. The results were expressed as mean values and standard deviation (SD) and further analysed using one-way analysis of variance (ANOVA) followed by a Tukey's HSD test with $\alpha=0.05$. Their treatment was carried out using the SPSS v.20.0 program.

\section{Results and discussion}

Tables 1 and 2 present the data obtained from an HPLC-DAD-MS analysis (retention time, $\lambda_{\max }$ in the visible 
Table 1 Retention time (Rt), wavelengths of maximum absorption in the visible region $\left(\lambda_{\text {max }}\right)$, mass spectral data, identification and quantification of phenolic compounds in hydromethanolic extracts and infusion of artichoke (mean $\pm S D)^{a}$

\begin{tabular}{|c|c|c|c|c|c|c|c|c|}
\hline \multirow[b]{2}{*}{ Compound } & \multirow{2}{*}{$\begin{array}{l}\mathrm{Rt} \\
(\mathrm{min})\end{array}$} & \multirow{2}{*}{$\begin{array}{l}\lambda_{\max } \\
(\mathrm{nm})\end{array}$} & \multirow{2}{*}{$\begin{array}{l}\text { Molecular } \\
\text { ion }[\mathrm{M}-\mathrm{H}]^{-} \\
(\mathrm{m} / \mathrm{z})\end{array}$} & \multirow{2}{*}{$\begin{array}{l}\operatorname{MS}^{2}(m / z) \\
(\% \text { base peak) }\end{array}$} & \multirow{2}{*}{$\begin{array}{l}\text { Tentative } \\
\text { identification }\end{array}$} & \multirow{2}{*}{$\begin{array}{l}\text { Identification } \\
\text { type }\end{array}$} & \multicolumn{2}{|c|}{ Quantification $\left(\mathrm{mg} \mathrm{g}^{-1}\right)$} \\
\hline & & & & & & & Hydromethanolic & Infusion \\
\hline 1 & 5.18 & 326 & 353 & $\begin{array}{l}\text { 191(100), 179(63), } \\
135(25)\end{array}$ & $\begin{array}{l}\text { 3-O-Caffeoylquinic } \\
\text { acid }\end{array}$ & $13,15,16,31-40$ & $0.10 \pm 0.00$ & nd \\
\hline 2 & 5.58 & $262 \operatorname{sh} 294$ & 153 & $109(100)$ & Dihydroxybenzoic acid & $\mathrm{DAD} / \mathrm{MS}$ & nd & $0.85 \pm 0.02$ \\
\hline 3 & 6.18 & $262 \operatorname{sh} 296$ & 153 & $109(100)$ & Protocatechuic acid & Standard/DAD/MS & $0.25 \pm 0.01$ & $0.23 \pm 0.01$ \\
\hline 4 & 6.84 & 310 & 337 & $\begin{array}{l}\text { 191(13), 173(6), } \\
\text { 163(96), 155(6), } \\
119(33)\end{array}$ & $\begin{array}{l}3 \text { - } p \text {-Coumaroylquinic } \\
\text { acid }\end{array}$ & $16,29,42$ & $0.07 \pm 0.00$ & nd \\
\hline 5 & 7.37 & 328 & 341 & 179(100), 135(89) & Caffeic acid hexoside & 16 & $0.13 \pm 0.00$ & $0.07 \pm 0.00$ \\
\hline 6 & 7.92 & 326 & 353 & $\begin{array}{l}191(100), 179(2), \\
161(2), 135(3)\end{array}$ & 5-O-Caffeoylquinic acid & Standard/DAD/MS & $0.49 \pm 0.01$ & nd \\
\hline 7 & 8.44 & $286 / 333$ & 191 & $\begin{array}{l}175(100), 148(33), \\
103(6)\end{array}$ & Quinic acid & Standard/DAD/MS & $0.21 \pm 0.01$ & $0.08 \pm 0.00$ \\
\hline 8 & 10.66 & 324 & 179 & $135(100)$ & Caffeic acid & Standard/DAD/MS & nd & $0.51 \pm 0.01$ \\
\hline 9 & 10.67 & 306 & 337 & $\begin{array}{l}\text { 191(5), 173(100), } \\
\text { 163(18), 155(5), } \\
\text { 119(10) }\end{array}$ & $\begin{array}{l}4-p \text {-Coumaroylquinic } \\
\text { acid }\end{array}$ & $\begin{array}{l}29,42, \text { Standard/ } \\
\mathrm{DAD} / \mathrm{MS}\end{array}$ & $0.12 \pm 0.00$ & nd \\
\hline 10 & 11.21 & 324 & 515 & $\begin{array}{l}353(95), 191(100), \\
179(65), 135(40)\end{array}$ & $\begin{array}{l}\text { 1,3-Dicaffeoylquinic } \\
\text { acid }\end{array}$ & $13,15,16,31-40$ & $0.37 \pm 0.02$ & $0.90 \pm 0.02$ \\
\hline 11 & 12.95 & 312 & 337 & $\begin{array}{l}\text { 191(100), 173(6), } \\
163(10), 119(4)\end{array}$ & $\begin{array}{l}\text { cis } 5 \text {-p-Coumaroylquinic } \\
\text { acid }\end{array}$ & $\begin{array}{l}\text { 29, } 42, \text { Standard/ } \\
\text { DAD/MS }\end{array}$ & $0.33 \pm 0.02$ & nd \\
\hline 12 & 13.19 & 356 & 639 & $477(80), 315(51)$ & $\begin{array}{l}\text { Methylquercetin- } O \text { - } \\
\text { hexoside- } O \text {-hexoside }\end{array}$ & $\mathrm{DAD} / \mathrm{MS}$ & nd & $0.14 \pm 0.01$ \\
\hline 13 & 13.90 & 306 & 337 & $\begin{array}{l}\text { 191(100), 173(3), } \\
163(4), 119(2)\end{array}$ & $\begin{array}{l}\text { trans } 5 \text { - } p \text {-Coumaroylquinic } \\
\text { acid }\end{array}$ & $\begin{array}{l}\text { 29, } 42, \text { Standard/ } \\
\text { DAD/MS }\end{array}$ & $0.03 \pm 0.00$ & nd \\
\hline 15 & 16.81 & 310 & 163 & $119(100)$ & $p$-Coumaric acid & Standard/DAD/MS & nd & $0.40 \pm 0.00$ \\
\hline 16 & 17.02 & 350 & 623 & 461(7), 285(100) & $\begin{array}{l}\text { Luteolin- } O \text {-hexoside- } \\
O \text {-glucuronide }\end{array}$ & $16, \mathrm{DAD} / \mathrm{MS}$ & $0.26 \pm 0.01$ & $0.46 \pm 0.01$ \\
\hline 17 & 19.26 & 350 & 477 & $301(100)$ & Quercetin-3-O-glucuronide & Standard/DAD/MS & $0.06 \pm 0.00$ & $0.09 \pm 0.00$ \\
\hline 18 & 20.26 & 340 & 607 & $269(100)$ & $\begin{array}{l}\text { Apigenin-4-O-hexoside-7- } \\
O \text {-glucuronide }\end{array}$ & 16, DAD/MS & $0.12 \pm 0.00$ & $0.31 \pm 0.02$ \\
\hline 20 & 20.70 & 344 & 461 & $285(100)$ & Luteolin-7-O-glucuronide & $\begin{array}{l}13,15,16,32,33 \\
35-37,39,40\end{array}$ & $0.70 \pm 0.02$ & $5.64 \pm 0.28$ \\
\hline 21 & 21.07 & 348 & 447 & $285(100)$ & Luteolin-7-O-glucoside & Standard/DAD/MS & $0.49 \pm 0.01$ & $2.88 \pm 0.05$ \\
\hline 22 & 22.95 & 330 & 515 & $\begin{array}{l}\text { 353(68), 191(100), } \\
\text { 179(20), 173(5), } \\
\text { 161(10), 135(7) }\end{array}$ & $\begin{array}{l}\text { 3,5-O-Dicaffeoylquinic } \\
\text { acid }\end{array}$ & $13,15,16,31-40$ & nd & $0.36 \pm 0.00$ \\
\hline 24 & 24.01 & 338 & 577 & $269(100)$ & Apigenin-7-O-rutinoside & $\begin{array}{l}13,15,16,32,33 \\
35-37,39,40\end{array}$ & $0.09 \pm 0.02$ & $0.16 \pm 0.02$ \\
\hline 25 & 24.38 & 352 & 623 & 315(16), 300(56) & $\begin{array}{l}\text { Methylquercetin- } O \text { - } \\
\text { rutinoside }\end{array}$ & $\mathrm{DAD} / \mathrm{MS}$ & $0.08 \pm 0.00$ & $0.07 \pm 0.00$ \\
\hline 26 & 25.51 & 336 & 445 & $269(100)$ & Apigenin-7-O-glucuronide & $\begin{array}{l}13,15,16,32,33 \\
35-37,39,40\end{array}$ & $0.20 \pm 0.00$ & $1.24 \pm 0.12$ \\
\hline 27 & 25.67 & 338 & 431 & $269(100)$ & Apigenin-7-O-glucoside & Standard/DAD/MS & $0.21 \pm 0.01$ & $0.68 \pm 0.02$ \\
\hline 28 & 29.30 & 340 & 431 & 285(100) & $\begin{array}{l}\text { Kaempferol-O- } \\
\text { deoxyhexosyl }\end{array}$ & DAD/MS & $0.04 \pm 0.01$ & $0.06 \pm 0.00$ \\
\hline \multirow[t]{4}{*}{29} & 34.51 & 346 & 285 & $\begin{array}{l}\text { 175(8), 151(8), } \\
133(5)\end{array}$ & Luteolin & Standard/DAD/MS & nd & $0.14 \pm 0.01$ \\
\hline & & & & & \multirow{3}{*}{\multicolumn{2}{|c|}{$\begin{array}{l}\text { Total phenolic acids } \\
\text { Total flavonoids } \\
\text { Total phenolic } \\
\text { compounds }\end{array}$}} & $2.12 \pm 0.04^{\mathrm{b}}$ & $3.40 \pm 0.06^{\mathrm{a}}$ \\
\hline & & & & & & & $2.25 \pm 0.01^{\mathrm{b}}$ & $11.89 \pm 0.39^{\mathrm{a}}$ \\
\hline & & & & & & & $4.37 \pm 0.05^{\mathrm{b}}$ & $15.29 \pm 0.33^{\mathrm{a}}$ \\
\hline
\end{tabular}

${ }^{a}$ nd, not detected; in each row, different letters mean significant differences $(p<0.05)$.

region, mass spectral data) used for the identification and quantification of phenolic compounds in S. marianum (milk thistle) and C. scolymus (artichoke), respectively. As an example, the HPLC phenolic profiles of their infusions, recorded at $370 \mathrm{~nm}$, can be observed in Fig. 1.

\section{Phenolic acids}

Protocatechuic acid (compound 3), 5-O-caffeolylquinic acid (compound 6), quinic acid (compound 7), caffeic acid (compound 8), and $p$-coumaric acid (compound 15) were positively 
Table 2 Retention time (Rt), wavelengths of maximum absorption in the visible region $\left(\lambda_{\text {max }}\right)$, mass spectral data, identification and quantification of phenolic compounds in hydromethanolic extract and infusion of milk thistle (mean \pm SD) ${ }^{a}$

\begin{tabular}{|c|c|c|c|c|c|c|c|c|}
\hline & & \multirow{2}{*}{$\begin{array}{l}\lambda_{\max } \\
(\mathrm{nm})\end{array}$} & \multirow{2}{*}{$\begin{array}{l}\text { Molecular ion } \\
{[\mathrm{M}-\mathrm{H}]^{-}} \\
(\mathrm{m} / \mathrm{z})\end{array}$} & \multirow{2}{*}{$\begin{array}{l}\operatorname{MS}^{2}(m / z) \\
(\% \text { base peak) }\end{array}$} & \multirow{2}{*}{$\begin{array}{l}\text { Tentative } \\
\text { identification }\end{array}$} & \multirow{2}{*}{$\begin{array}{l}\text { Identification } \\
\text { type }\end{array}$} & \multicolumn{2}{|c|}{ Quantification ( $\left.\mathrm{mg} \mathrm{g}^{-1}\right)$} \\
\hline Compound & $(\min )$ & & & & & & Hydromethanolic & Infusion \\
\hline 5 & 7.44 & 328 & 341 & 179(100), 135(22) & Caffeic acid hexoside & $\mathrm{DAD} / \mathrm{MS}$ & $0.12 \pm 0.00$ & $0.05 \pm 0.01$ \\
\hline 6 & 8.11 & 326 & 353 & $\begin{array}{l}\text { 191(100), 179(4), } \\
173(7), 135(5)\end{array}$ & 5-O-Caffeolyquinic acid & Standard/DAD/MS & $0.56 \pm 0.02$ & $0.15 \pm 0.02$ \\
\hline 13 & 13.19 & 312 & 337 & $\begin{array}{l}\text { 191(100), 173(7), } \\
163(9), 119(5)\end{array}$ & 5- $p$-Coumarolyquinic acid & $\begin{array}{l}\text { 29, } 42, \text { Standard/ } \\
\text { DAD/MS }\end{array}$ & $0.12 \pm 0.00$ & $0.03 \pm 0.01$ \\
\hline 15 & 17.10 & 306 & 163 & $119(100)$ & $p$-Coumaric acid & Standard/DAD/MS & $0.11 \pm 0.01$ & $0.11 \pm 0.01$ \\
\hline 19 & 20.27 & 322 & 661 & $\begin{array}{l}499(100), 337(11), \\
\text { 179(11), 173(87), } \\
\text { 163(14), 119(8) }\end{array}$ & $\begin{array}{l}\text { 5-p-Coumarolyquinic } \\
\text { acid dihexoside }\end{array}$ & $\mathrm{DAD} / \mathrm{MS}$ & $0.11 \pm 0.00$ & $0.38 \pm 0.03$ \\
\hline 20 & 20.77 & 350 & 461 & $285(100)$ & Luteolin-7-O-glucuronide & $\mathrm{DAD} / \mathrm{MS}$ & $0.58 \pm 0.01$ & $1.17 \pm 0.09$ \\
\hline 26 & 25.48 & 338 & 445 & $269(100)$ & Apigenin-7-O-glucuronide & $\mathrm{DAD} / \mathrm{MS}$ & $1.26 \pm 0.01$ & $3.14 \pm 0.12$ \\
\hline & & & & & Total phenolic acids & & $1.65 \pm 0.04^{\mathrm{a}}$ & $0.91 \pm 0.09^{\mathrm{b}}$ \\
\hline & & & & & Total flavonoids & & $1.94 \pm 0.01^{\mathrm{b}}$ & $4.66 \pm 0.18^{\mathrm{a}}$ \\
\hline & & & & & Total phenolic compounds & & $3.56 \pm 0.05^{\mathrm{b}}$ & $5.57 \pm 0.27^{\mathrm{a}}$ \\
\hline
\end{tabular}

${ }^{a}$ In each row, different letters mean significant differences $(p<0.05)$.
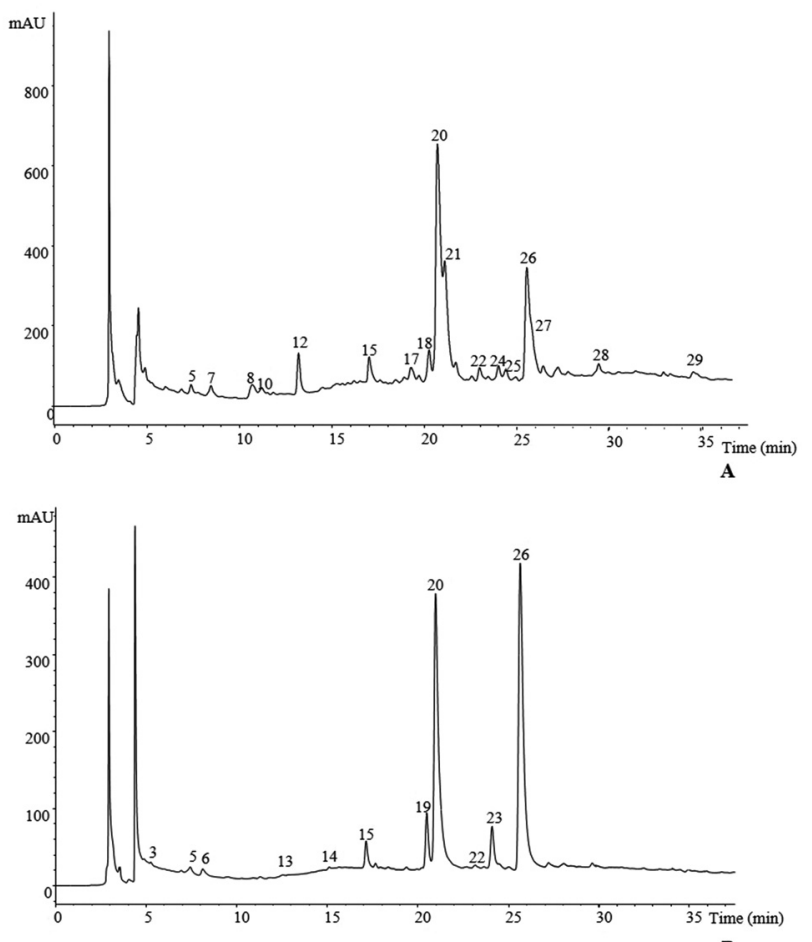

Fig. 1 Phenolic profile of the infusion of artichoke (A) and milk thistle (B) recorded at $370 \mathrm{~nm}$. The profile was obtained using a Spherisorb S3 ODS-2 $\mathrm{C}_{18}$ column thermostatted at $35{ }^{\circ} \mathrm{C}$ using a flow rate of $0.5 \mathrm{~mL}$ $\mathrm{min}^{-1}$ and with gradient elution: (a) $0.1 \%$ formic acid in water and (b) acetonitrile. identified according to their retention time, mass and UV-vis characteristics by a comparison with commercial standards.

Hydroxycinnamic acid derivatives were detected in both samples, being mostly quinic acid derivatives, whose identities were assigned based on their MS spectra and fragmentation patterns. The assignments of the different caffeoylquinic, feruloylquinic and $p$-coumaroylquinic acid isomers were made using the recommended IUPAC numbering system and also the hierarchical keys previously developed by Clifford et al. ${ }^{29,30}$

Compound $1\left([\mathrm{M}-\mathrm{H}]^{-}\right.$at $m / z$ 353) was identified as 3-Ocaffeoylquinic acid, yielding the base peak at $m / z 191$ ([quinic acid- $\mathrm{H}]^{-}$) and the ion at $m / z 179$ ([caffeic acid-H $]^{-}$) with an intensity $>63 \%$ base peak, characteristic of 3-acylchlorogenic acids as reported by Clifford et $a l^{29,30}$ Monocaffeoylquinic acids have been largely reported by many authors in different parts of artichoke, such as heads and leaves, ${ }^{13,15,31-38}$ hearts, ${ }^{16}$ wastes such as bracts, receptacles and stems from the fruit, ${ }^{39}$ juices and pomace, ${ }^{15,32}$ and in dietary supplements. ${ }^{15,37,40}$

Compound 22 present in milk thistle and artichoke was identified as 3,5-O-dicaffeoylquinic acid based on its fragmentation pattern being similar to that reported by Clifford et al. ${ }^{30}$ The $\mathrm{MS}^{2}$ base peak was at $m / z 191$, but also presented a very high relative abundance at $m / z 353$, produced by the loss of one of the caffeoyl moieties [M - H-caffeoyl $]^{-}$, whose subsequent fragmentation yielded the same fragments as 5-Ocaffeoylquinic acid at $m / z 191,179$ and 135. Compound 10 (artichoke) was identified as 1,3-O-dicaffeoylquinic acid (cynarin) according to its $\mathrm{MS}^{2}$ fragmentation and elution characteristics, being the most hydrophilic dicaffeoylquinic acid. ${ }^{41}$ Dicaffeoylquinic acids have been extensively reported in 
hydroalcoholic extracts obtained from different parts of artichoke, as mentioned above. ${ }^{13,15,16,31-36,38-40}$

Four signals in artichoke (compounds 4, 9, 11 and 13) showed a pseudomolecular ion $\left([\mathrm{M}-\mathrm{H}]^{-}\right.$) at $\mathrm{m} / \mathrm{z} 337$ (Tables 1 and 2). These compounds were assigned as the 3-acyl, 4-acyl and 5-acyl isomers of $p$-coumaroylquinic acid based on their HPLC retention and $\mathrm{MS}^{2}$ fragmentation characteristics, as previously reported by Clifford et al. ${ }^{29,42}$ Thus, compound 4 (artichoke) was tentatively identified as 3-p-coumaroylquinic acid, yielding the base peak at $m / z 163$ ([coumaric acid-H] $]^{-}$). Fragmentation of compound $\mathbf{9}$ with a majority $\mathrm{MS}^{2}$ product ion at $m / z 173$ was coherent with 4-p-coumaroylquinic acid, whereas compound 13 (artichoke and milk thistle), yielding the base peak at $m / z 191$, was identified as trans 5-p-coumaroylquinic acid. The latter compound was also found in the analyzed milk thistle extracts. Compound $\mathbf{1 1}$ (artichoke) with a UV spectrum and a $\mathrm{MS}^{2}$ fragmentation pattern identical to that of compound 13 was tentatively assigned as the cis isomer of $5-p$ coumaroylquinic acid. This tentative assignment was supported by the observation that hydroxycinnamoyl cis derivatives are expected to elute before the corresponding trans ones, as previously observed before and after UV irradiation (366 nm, $24 \mathrm{~h}$ ) of hydroxycinnamic derivatives in our laboratory. ${ }^{43}$ Furthermore, in milk thistle, compound 19 with $162+$ $162 \mathrm{mu}$ (glucosyl moieties) higher than compound 13 was tentatively identified as 5-p-coumarolyquinic acid dihexoside (Table 1). As far as we are aware, except for 3-p-coumaroylquinic acid identified in artichoke heart by Abu-Reidah et al. ${ }^{16}$ none of these $p$-coumaroylquinic acid derivatives has been previously reported either in artichoke or in milk thistle.

Compound 14 in milk thistle was identified as 5-O-feruloylquinic acid taking into account its pseudomolecular ion $\left([\mathrm{M}-\mathrm{H}]^{-}\right.$at $\left.m / z 367\right)$ and $\mathrm{MS}^{2}$ fragmentation similar to that of 5-O-caffeoylquinic acid. This compound was previously identified in artichoke samples, ${ }^{16,37}$ but, as far as we know, it has not been reported in milk thistle.

Compound 5 present in milk thistle and artichoke showed a pseudomolecular ion $[\mathrm{M}-\mathrm{H}]^{-}$at $m / z 341$, releasing an $\mathrm{MS}^{2}$ fragment at $\mathrm{m} / \mathrm{z} 179$ ([caffeic acid-H $]^{-}$) from the loss of a hexosyl moiety (-162 mu) that was tentatively assigned as caffeic acid hexoside. That compound was also identified in hydroalcoholic extracts of artichoke hearts by Abu-Reidah et al. ${ }^{16}$

Finally, compound 2 (artichoke) with the same UV and mass characteristics as compound $\mathbf{3}$ (protocatechuic acid, i.e. 3,4-dihydroxybenzoic acid) was just tentatively assigned as a dihydroxybenzoic acid. Protocatechuic acid was previously reported in hydroalcoholic extracts of artichoke wastes (bracts, receptacles and stems from the fruit) by Sánchez-Rabaneda et al. $^{39}$

\section{Flavonoids}

Compounds 16, 21 and 29 in artichoke and compound 20 in both samples were identified as luteolin derivatives according to their UV and mass spectra characteristics (Tables 1 and 2). Compounds 21 and 29 were positively identified as luteolin-7-
$O$-glucoside (cynaroside) and luteolin, respectively, by a comparison with commercial standards, being also largely identified in artichoke hearts, ${ }^{16}$ leaves and heads, ${ }^{13,15,31,32,34-37}$ juices and pomace, ${ }^{15,32}$ and dietary supplements. ${ }^{15,37,40}$

Compound 20 presented a pseudomolecular ion $[\mathrm{M}-\mathrm{H}]^{-}$ at $m / z 461$ releasing a fragment ion at $m / z 285\left([\mathrm{M}-176]^{-}\right.$, loss of a glucuronyl moiety); although the position of the glycosyl moiety could not be established it was assigned to luteolin 7-O-glucuronide, owing to the identification of that compound in leaves, heads, hearts, juices, pomaces and dietary supplements of artichoke, mostly obtained after hydroalcoholic extraction. ${ }^{13,15,16,32,33,35-37,39,40}$ Compound 16 presented a pseudomolecular ion $[\mathrm{M}-\mathrm{H}]^{-}$at $\mathrm{m} / \mathrm{z} 623$, yielding fragment ions at $\mathrm{m} / \mathrm{z} 461$ (-162 mu; loss of a hexosyl residue) and 285 (-176 mu; loss of a glucuronyl residue), which allowed its assignment as luteolin- $O$-hexoside- $O$-glucuronide. Two compounds with similar characteristics were reported by Abu-Reidah et al. ${ }^{16}$ in artichoke hearts, without assigning the position of substitution of the glycosyl residues.

In accordance with their UV and mass spectra characteristics, different apigenin derivatives were also detected in the analysed samples. Compounds 24, 27 (artichoke) and 26 (artichoke and milk thistle) showed pseudomolecular and fragment ions coherent with deoxyhexosyl-hexoside, hexoside and glucuronide derivatives of apigenin, respectively. The presence of apigenin-7-O-rutinoside, apigenin-7-O-glucuronide and apigenin-7-O-glucoside in different parts of artichoke was consistently reported by the previously mentioned authors, so that those identities could also be tentatively assumed for the compounds detected herein. Furthermore, the identity of apigenin7-O-glucoside (compound 27) was here confirmed by a comparison with a commercial standard.

The pseudomolecular ion of compound $\mathbf{1 8}$ in artichoke $\left([\mathrm{M}-\mathrm{H}]^{-}\right.$at $\mathrm{m} / z$ 607) released a fragment ion at $\mathrm{m} / z 269$ ([M - 162-176] $]^{-}$; apigenin), which allowed its tentative identification as an apigenin- $O$-hexoside- $O$-glucuronide. A compound with similar characteristics was identified as apigenin4-O-hexoside-7-O-glucuronide by Abu-Reidah et al. ${ }^{16}$ in artichoke hearts. Another apigenin derivative (compound 23) was detected in the sample of milk thistle, whose mass characteristics $\left([\mathrm{M}-\mathrm{H}]^{-}\right.$at $\mathrm{m} / \mathrm{z} 591$ releasing a fragment ion at $\mathrm{m} / \mathrm{z} 269$ $\left([\mathrm{M}-146-176]^{-}\right)$from the loss of deoxyhexosyl and glucuronyl moieties) pointed to an apigenin- $O$-deoxyhexosyl-glucuronide. To our knowledge, this compound has not been previously described in milk thistle samples.

The following compounds were only present in artichoke. Compound $17\left([\mathrm{M}-\mathrm{H}]^{-}\right.$at $\left.m / z 477\right)$ presented UV spectra with $\lambda_{\text {max }}$ around $350 \mathrm{~nm}$ and an $\mathrm{MS}^{2}$ product ion at $\mathrm{m} / \mathrm{z} 301$; comparison with a standard obtained in our laboratory ${ }^{44}$ allowed its identification as quercetin 3-O-glucuronide. Compound 12 $\left([\mathrm{M}-\mathrm{H}]^{-}\right.$at $\left.m / z 639\right)$ released fragment ions at $m / z 477$ and 315 , from the consecutive losses of $162 \mathrm{mu}$ (two hexosyl moieties). The ion at $m / z 315$ can be attributed to a methylquercetin, whilst the high abundance of the ion at $\mathrm{m} / \mathrm{z} 477$ indicated that each hexosyl group was located at different positions of the aglycone. Therefore, the compound was tentatively 
assigned as methylquercetin- $O$-hexoside- $O$-hexoside. Compound $25\left([\mathrm{M}-\mathrm{H}]^{-}\right.$at $\left.\mathrm{m} / \mathrm{z} 623\right)$ released fragment ions at $\mathrm{m} / \mathrm{z}$ 315 and 300 (further loss of a methyl group) also suggesting a methylquercetin. In this case, the loss of $308 \mathrm{mu}(146+$ $162 \mathrm{mu}$ ) to yield the aglycone suggested the existence of deoxyhexose and hexose as glycosylating substituents, probably constituting a disaccharide owing to their joint loss. Although there was no further indication of the type of sugar, it might be a rutinose taking into account the previous identification of quercetin-3-O-rutinoside in hydroalcoholic extracts of artichoke samples by Sánchez-Rabaneda et al. ${ }^{39}$ and Abu-Reidah et $a .^{16}$ Thus, the compound was tentatively assigned as methylquercetin $\mathrm{O}$-rutinoside. Finally, compound $\mathbf{2 8}$ with a pseudomolecular ion $[\mathrm{M}-\mathrm{H}]^{-}$at $\mathrm{m} / \mathrm{z} 431$ yielding a product ion at $m / z 285$ (-146 mu, loss of a deoxyhexosyl moiety) could be associated with a kaempferol-O-deoxyhexoside. As far as we know, none of the latter four compounds has been described in artichoke.

In both species, infusions presented higher phenolic contents than their hydromethanolic extracts. Milk thistle preparations presented the same composition, revealing only differences in the quantities obtained. Nevertheless, artichoke revealed a different profile between infusions and hydromethanolic extracts. These differences can be mainly due to the heat treatment to which infusions were subjected. Apigenin-7-O-glucuronide was the major flavonoid found in milk thistle (Table 1), while luteolin-7-O-glucuronide was the most abundant in artichoke (Table 2).

In the literature, the milk thistle phenolic composition is characterized by seven flavonolignans (silymarin). ${ }^{12,14,17,19,21,23-27,31}$ These compounds are known to be normally present in seeds of milk thistle. ${ }^{17,19}$ Therefore, it can be concluded that the sample studied by us did not contain seeds, but only the other parts of the plant, even though the label mentioned the whole plant material.

Despite the many articles reporting the phenolic composition of artichoke hydroalcoholic extracts, ${ }^{13,15,16,31-40}$ the present work characterizes the phenolic composition in infusions. Moreover, infusion is the most common form to consume this plant and, to our knowledge, this is also the first report presenting results for the whole plant material and not seeds. The literature reports mainly the existence of caffeoylquinic acid, and luteolin and apigenin derivatives, as also observed in the present study. Nevertheless, the studied sample of artichoke also presented other compounds.

\section{Conclusions}

Overall, both artichoke and milk thistle represent a good source of bioactive compounds, especially phenolic acids and flavonoids, that are more enhanced in the infusion preparations. This study also provides the reason for the traditional and current use of these plants in different formulations (dry material, pills and syrups) by deepening our knowledge of the main responsible bioactive compounds. Moreover, these plants can be used not only as excellent sources of antioxidants but also as potential natural remedies that can be easily included in the diet, thereby preventing and healing chronic diseases.

\section{Competing interests}

The authors declare no competing financial interest.

\section{Acknowledgements}

The authors are grateful to the Foundation for Science and Technology (FCT, Portugal) for financial support to the research center CIMO (strategic project PEst-OE/AGR/UI0690/ 2011) and an L. Barros researcher contract under the "Programa Compromisso com Ciência - 2008”.

\section{References}

1 I. C. W. Arts and P. C. H. Hollman, Am. J. Clin. Nutr., 2005, 81, 317S-325S.

2 P. Brat, S. Georgé, A. Bellamy, L. Du Chaffaut, A. Scalbert, L. Mennen, N. Arnault and M. J. Amiot, J. Nutr., 2006, 136, 2368-2373.

3 R. Chirinos, R. Pedreschi, H. Rogez, Y. Larondelle and D. Campos, Ind. Crops Prod., 2013, 47, 145-152.

4 M. Segasothy and P. A. Phillips, Int. J. Med., 1999, 92, 531544.

5 C. Ruxton, E. Gardner and D. Walker, Int. J. Food Sci. Nutr., 2006, 57, 249-272.

6 S. Miccadei, D. D. Venere, A. Cardinali, F. Romano, A. Durazzo, M. S. Foddai, R. Fraioli, S. Mobarhan and G. Maiani, Nutr. Cancer, 2008, 60, 276-283.

7 F. J. Barba, M. J. Esteve and A. Frígola, Stud. Nat. Prod. Chem., 2014, 41, 321-346.

8 A. Scalbert, T. Johnson and M. Saltmarsh, Am. J. Clin. Nutr., 2005, 81, 215S-217S.

9 C. A. Rice-Evans and N. J. Miller, Biochem. Soc. Trans., 1996, 24, 790-795.

10 W. Zheng and S. Y. Wang, J. Agric. Food Chem., 2001, 49, 5165-5170.

11 M. Carocho and I. C. F. R. Ferreira, Anti-Cancer Agents Med. Chem., 2013, 13, 1236-1258.

12 J. I. Lee, M. Narayan and J. S. Barrett, J. Chromatogr., B: Biomed. Appl., 2007, 845, 95-103.

13 G. Pandino, F. L. Courts, S. Lombardo, G. Mauromicale and G. Williamson, J. Agric. Food Chem., 2010, 58, 10261031.

14 K. Wang, H. Zhang, L. Shen, Q. Du and J. Li, J. Pharm. Biomed. Anal., 2010, 53, 1053-1057.

15 S. C. Gouveia and P. C. Castilho, Food Res. Int., 2012, 48, 712-724. 
16 I. M. Abu-Reidah, D. Arráez-Román, A. Segura-Carretero and A. Fernández-Gutiérrez, Food Chem., 2013, 141, 22692277.

17 H. S. Althagafy, T. N. Graf, A. A. Sy-Cordero, B. T. Gufford, M. F. Paine, J. Wagoner, S. J. Polyak, M. P. Croatt, N. H. Oberlies and N. H. Oberlies, Bioorg. Med. Chem., 2013, 21, 3919-3926.

18 V. Lattanzio, P. A. Kroon, V. Linsalata and A. Cardinali, J. Funct. Food, 2009, I, 131-144.

19 L. Calani, F. Brighenti, R. Bruni and D. Del Rio, Phytomedicine, 2012, 20, 40-46.

20 N. J. Jun, K. C. Jang, S. C. Kim, D. Y. Moon, K. C. Seong, K. H. Kang, L. Tandang, P. H. Kim, S. K. Cho and K. H. Park, J. Appl. Biol. Chem., 2007, 50, 244-248.

21 A. R. Bilia, D. Salvini, G. Mazzi and F. F. Vincieri, Chromatographia, 2001, 53, 210-215.

22 A. R. Bilia, M. C. Bergonzi, S. Gallori, G. Mazzi and F. F. Vincieri, J. Pharm. Biomed. Anal., 2002, 30, 613-624.

23 Y. Zhao, B. Chen and S. Yao, Pharm. Biomed. Anal., 2005, 38, 564-570.

24 S. Kéki, K. Tóth, M. Zsuga, R. Ferenczi and S. Antus, Rapid Commun. Mass Spectrom., 2007, 21, 2255-2262.

25 J. I. Lee, B. H. Hsu, D. Wu, J. S. Barrett and J. S. Barrett, J. Chromatogr., A, 2006, 1116, 57-68.

26 X.-L. Cai, D.-N. Li, J.-Q. Qiao, H.-Z. Lian and S.-K. Wan, Asian J. Chem., 2009, 21, 63-74.

27 B. J. Brinda, H. J. Zhu and J. S. Markowitz, J. Chromatogr., B, 2012, 902, 1-9.

28 Y. Vaknin, R. Hadas, D. Schafferman, L. Murkhovsky and N. Bashan, Int. J. Food Sci. Nutr., 2008, 59, 339-346.

29 M. N. Clifford, K. L. Johnston, S. Knight and N. A. Kuhnert, J. Agric. Food Chem., 2003, 51, 2900-2911.

30 M. N. Clifford, S. Knight and N. A. Kuhnert, J. Agric. Food Chem., 2005, 53, 3821-3832.
31 M. Wang, J. E. Simon, I. F. Aviles, K. He, Q. Y. Zheng and Y. Tadmor, J. Agric. Food Chem., 2003, 51, 601-608.

32 K. Schütz, D. Kammerer, R. Carle and A. Schieber, J. Agric. Food Chem., 2004, 52, 4090-4096.

33 R. Ferracane, N. Pellegrini, A. Visconti, G. Graziani, E. Chiavaro, C. Miglio and V. Fogliano, J. Agric. Food Chem., 2008, 56, 8601-8608.

34 S. Lombardo, G. Pandino, G. Mauromicale, M. Knödler, R. Carle and A. Schieber, Food Chem., 2010, 119, 11751181.

35 G. Pandino, S. Lombardo, G. Mauromicale and G. Williamson, J. Food Compos. Anal., 2011, 24, 148-153.

36 G. Pandino, S. Lombardo, G. Mauromicale and G. Williamson, Food Chem., 2011, 126, 417-422.

37 M. A. Farag, S. H. El-Ahmady, F. S. Elian and L. A. Wessjohann, Phytochemistry, 2013, 95, 177-187.

38 J. Wu, Y. Qian, P. Mao, L. Chen, Y. Lu and H. Wang, J. Chromatogr., B: Biomed. Appl., 2013, 927, 173-180.

39 F. Sánchez-Rabaneda, J. Jáuregui, R. M. Lamuela-Raventós, J. Bastida, F. Viladomat and C. Codina, J. Chromatogr., A, 2003, 1008, 57-72.

40 K. Schütz, E. Muks, R. Carle and A. Schieber, J. Agric. Food Chem., 2006, 54, 8812-8817.

41 M. N. Clifford, W. Wu, J. Kirkpatrick and N. A. Kuhnert, J. Agric. Food Chem., 2007, 55, 929-936.

42 M. N. Clifford, W. Zheng and N. Kuhnert, Phytochem. Anal., 2006, 17, 384-393.

43 L. Barros, M. Dueñas, A. M. Carvalho, I. C. F. R. Ferreira and C. Santos-Buelga, Food Chem. Toxicol., 2012, 50, 15761582.

44 M. Dueñas, H. M. Chronet, J. J. Pérez-Alonso, R. D. PaolaNaranjo, A. M. González-Paramás and C. Santos-Buelga, Eur. Food Res. Technol., 2008, 227, 1069-1076. 